\title{
Issues related to the adoption of e-books in academic libraries: a literature review
}

\author{
Michelle Kahn ${ }^{1}$ and Peter G. Underwood ${ }^{2}$ \\ michelle.kahn@uct.ac.za, peter.underwood@uct.ac.za
}

\begin{abstract}
Received: 30 October 2013
Accepted: 20 December 2013
\end{abstract}

\begin{abstract}
While e-journals have successfully been integrated into academic library collections, the same cannot be said about e-books. In this paper, the obstacles to e-book adoption in academic libraries in general is discussed using a review of the English-language literature published over the period 2007 to 2013. Issues identified are the changing roles of libraries in the digital age; collection development strategies; complex e-book purchase models offered to libraries; questions of copyright, licensing and digital rights management; format considerations; and availability of hardware and software on which to read e-books. Libraries continue to face these challenges today.
\end{abstract}

Keywords: E-books, academic libraries, collection management

\section{Introduction}

Anderson writes that "it is now generally assumed and expected that the majority of a research library's journal collection and reference resources will be available electronically" (2009: 133). Users accept that, should they need access to a journal article or a reference work, looking online is their first course of action. These days, looking online for academic book material is becoming more common, and a range of e-books is available to users. Libraries, by now familiar with processes around including e-journals in their collections, are having to deal with issues surrounding introducing a variety of different e-books into their collections. They have found that dealing with e-books is both different from dealing with print books and dealing with e-journals. A close examination of the issues of adopting and using e-books in libraries is needed to determine what the obstacles are to integration of e-books into academic library collections. This paper, therefore, is a review of the literature on the adoption of e-books in academic libraries published between 2007 and 2013 , with a few exceptions of some older works of significance. It is confined to English-language material and limited to studies done in the United Kingdom, the United States, Australia and South Africa. Once practical issues of e-book adoption have been identified, the questions of whether patrons are interested in using e-books, if they are currently using them, how they use them and how they could potentially use them become pertinent. These questions will not be discussed in this paper.

Galbraith has noted that the publishers who were quickest to adopt e-books were those who were already successful e-journal publishers, like Springer and Elsevier (Galbraith 2011: 10). E-journal articles typically come as part of a database package and initially e-books were offered as part of these database packages (Anderson 2009: 133). The consequence of e-books residing in databases made up predominantly of e-journals is that there is a certain amount of confusion among users as to the difference between e-journals and e-books. Abdullah and Gibb noticed that even regular e-book users get the two types of e-resources confused (Abdullah \& Gibb 2008: 603).

As will be discussed, this confusion is only one of the many issues identified in the literature that libraries have to overcome for e-book integration to reach the same level of e-journal integration, and for all parties - libraries, publishers and patrons - to be happy with the outcome.

\section{The traditional view and role of libraries}

With the widespread use of the World Wide Web, the availability of digital versions of a range of material and with user expectations therefore changing, the view and role of the traditional library - that of a building to visit in order to consult and borrow books and journals - is no longer applicable in much of the academic world. As Anderson asserts, "the library is not about books; it's about information" (Anderson 2008: 564). Thus, academic libraries must offer access to online resources or become obsolete, a concept very different to that of the traditional library where physical books played a major role. With a change in the way libraries operate comes the need for librarians to be willing and able to change as well.

There are many reasons some librarians object to the introduction of e-books to their libraries. One of the reasons is that e-books are not material objects and the money spent on them is not immediately obvious because the books are not physically part of the library's collection (Schell 2011: 83). In addition, the re-allocation of funds from print books results in a smaller print collection, adding to the decrease in objects for the library to put on its shelves. Another objection by librarians is that subscription or pay-per-view e-book business models, with their "big deals" or patron-driven purchases, may give the impression that librarians are no longer in charge of title selection, suggesting that they have lost control over their collection or do not have the necessary expertise to make the right choices (Schell 2011: 83).

1. Michelle Kahn is a lecturer in the Library and Information Studies Centre, University of Cape Town.

2. Peter G. Underwood is Emeritus Professor of Librarianship, University of Cape Town. 
Other issues for traditional librarians are that e-books threaten the library's role as archive because e-books are not owned outright, but are usually loaned from aggregators; librarians are also concerned that they are not serving their community effectively because of the perception that patrons do not want e-books (Schell 2011: 83). An additional concern is the uncertainty of the privacy of patrons once e-books are added to collections (Chartered Institute of Library and Information Professionals [CILIP] Policy Department 2012: 10) - since much electronic activity can be tracked, patron privacy might not be able to be guaranteed.

Many of these concerns could be addressed by changing the attitudes and perceptions of libraries and librarians. In an opinion piece about the future of libraries, Medeiros writes that the issue is that libraries (and librarians) deal with books (2011: 85). Once the perception of libraries as places for information rather than places for books changes - and as the attitudes of librarians change - the introduction of e-books will gain more acceptance. Librarians will cease to worry about the size of their physical collection and the proportion of print books to e-books. They will find ways to ensure they have a measure of control over e-book titles. They will also come to see the value of the digital archive.

Even once attitudes have changed, the process of introducing e-books to libraries is not a simple one. The usual systems used for collection, organisation, and preservation that are suitable for print collections are being challenged by the introduction of electronic material (Zhao \& Zhao 2010: 94).

Zhao and Zhao write that many libraries do not have comprehensive policies in place when it comes to managing their e-books (2010: 95). In addition, they note that standards for records have not yet been set which could be the reason policies have not yet been established (2010: 96). According to Gardiner and Musto, the reason the CD-ROM lost its appeal for libraries - which led to publishers discontinuing their wide use - is that libraries did not know how to catalogue them (2010: 166). While MARC records are provided with many e-books, there is no standard as to their extensiveness (Zhao \& Zhao 2010: 97; Schell 2011: 91). Setting e-book cataloguing standards should be a priority (Zhao \& Zhao 2010: 102).

A big issue for cataloguers is that of inventory control. Because an e-book can relatively easily be withdrawn from a library's collection (for whatever reason), Zhao and Zhao say that collections are not stable which adds to the difficulty of cataloguing them (2010: 100). A catalogue entry for an e-book does not disappear once access to the e-book is withdrawn, so keeping an up-to-date catalogue is a near-impossibility. Some libraries, therefore, have chosen not to include e-books in their library catalogues until a solution to the problem is found. For this reason, e-journals and e-books have their own discovery tool separate from the catalogue. For Vasileiou, Rowley and Hartley (2012: 285), the fact that there is no single discovery tool able to meet the needs of all resources in the library is problematic. It not only scatters the catalogue function, but is confusing for users. Library administrators should be striving for one discovery tool for the entire collection.

To encourage the growth of their e-book collections, libraries and librarians need to move out of their traditional roles. A change of attitude about what makes a "good" overall collection and a commitment to improving the processes involved in the curation of new technologies will go a long way to encouraging growth of e-book collections.

\section{Collection development}

There are those who see little future for print in library collections. Anderson (2009: 140) recommends that libraries, publishers and vendors firstly accept and then adapt to the fact that print is being marginalised. Gomez (2008), writing about the demise of print, would agree. More often, though, the feeling in the literature is that both forms serve a purpose. Both should therefore be included in the collection management of an institution.

Breeding (2012) stresses the importance of library collections not committing to an "either / or" strategy of growing only print or only electronic titles. In reality, he says, most library collections are "heterogeneous" comprising titles in a variety of formats: print, digital and electronic (2012: 23). He feels that the challenge for libraries is not about choosing which format is "best', but on focusing on the best management of the mixed collection that they have. Joint (2010) agrees that libraries need to view their electronic collections as equal to, not better or worse than, their print collections in order to make choosing one over the other easier.

In a University College London study of a large group, Rowlands et al., (2007: 504), found that the use of e-books was related to dissatisfaction with the print collection, especially in the disciplines of engineering and sciences. This finding gives the impression that users are still eager to make use of the print collection and would do so if they were provided with the required materials. The JISC National E-books Observatory project (hereafter, JISC Observatory project) collected data on e-textbook use from over 120 universities across the United Kingdom. Its user surveys found that, even if users were dissatisfied with the print collection, they would be less likely to complain about the print books in the collection where there was access to e-books (Rowlands et al. 2009: 14). Users did not feel that using the print book was a necessity but, rather, were happy with access to whatever version was available, particularly for short loan books. An earlier study conducted in 2004 at Duke University Libraries on the use of print books and their electronic counterparts had found that $39 \%$ of titles had been used in both print and electronic formats, suggesting a "format agnosticism" similar to that found during the JISC Observatory project (Littman \& Connaway 2004: 261).

Medeiros reports on a yearlong patron-driven acquisition pilot that ran in a small library consortium examining, among other things, what effect the programme had on the circulation of corresponding print titles. The theory was that, on discovering a title via the e-book database, patrons would use the information to seek out the print book instead. While a direct link between the two could not be ascertained, it was noticed that the print and electronic copies tended to circulate within two weeks of each other (Medeiros 2012: 65). 
Some disciplines are heavier users of monographs than others, and some have a higher affinity for using electronic versions. Determining which subject areas make more use of e-books should provide guidance to libraries on collection development in these areas. Tucker's study (2012) at the University of Nevada, Las Vegas Libraries sought to explore, among other things, which subject areas had the highest use of e-books by looking at the circulation rates of each subject collection. His paper explains the usefulness of identifying subject areas that are heavier users of e-books and skewing the collection development strategy that way. Each institution will be different and should strive to be aware of those subject areas which demand e-books the most.

Should a library embark on a collection development programme for academic e-books, there is still the question of the availability of quality content to be considered; some titles are simply not available as e-books, or not in the format or business model which the library requires. Lack of academic content is a big obstacle in the growth of e-book collections in academic libraries (Dewan 2012: 31). Zinn and Langdown's study of South African academic librarians' use of e-books found that print is still preferred among this group, perhaps partly because of the dearth of material available in e-book format (2011: 110). The same preference was displayed by a group of prominent South African researchers; availability of e-content was proposed as a reason for their choice (Treptow \& James, 2011: 67). Link (2012) reports on a small-sample study at the College of New Jersey Library that examined the circulation of a small selection of print books in the collection which would be possible to replace with electronic versions. The aim of the study was to ascertain whether it would be wise to stop the collection of print books in favour of e-books. While the study showed that the library user would benefit from having the option of accessing popular print titles in electronic format, discarding print from the collection, as a whole, was not recommended because of the comparatively few titles that are presently available as ebooks.

A starting point for libraries committing to growing e-book collections is a collection development policy. The policy is what guides librarians in the expansion, organisation and maintenance of the library's collection, addressing issues such as its size and potential for growth. Collection development policies help to maintain the standard to which the library strives and to satisfy users' needs.

An IFLA draft paper on e-resource collection development suggests that policies include sections on the selection and evaluation of e-resources, their licensing, and their review and renewal processes (Johnson et al. 2012). In some instances, like the selection of content, policies for e-resources will be similar to those for print collections, but when considering, for example, technical issues, use, support from suppliers, pricing models, and licensing of e-resources, collection development policies must be developed specifically for e-resources (Johnson et al. 2012).

Because of the relative newness of e-books in libraries, it is crucial to review and revise the policy often to assist with making e-books an established part of the library collection - advances in technology, changes in budgets and changes in the needs of the library community demand regular policy review (Vasileiou, Rowley \& Hartley 2012: 285). Patterns of use should also be studied to determine if the mix of content is right.

Building collections is a complex exercise with many factors affecting decisions, some of which are more or less important, depending on the institution (Vasileiou, Hartley \& Rowley 2012). The way each factor should be dealt with must be addressed in the policy. For e-books, policies should address the complicated matters of business models and licensing in particular. Price (2009) writes that, considering the high costs of e-resources, collection development policies are even more important in times of budgetary constraints, such as most libraries are experiencing today.

\section{Business models}

Publishing is an industry and, in order to remain in business, publishers have to produce a profit. A general misconception is that digital publishing is far cheaper than print publishing because of the ink, paper and distribution costs that do not need to be taken into consideration. There is a large amount of work that goes into the creation of a monograph before the printing stage, all of which has to be absorbed within the cost of the end product (Thompson 2005: 317). The task of producing reliable content, which may involve paying an author, researchers and an editor, is a large cost in itself. The quality of the editorial work is, after all, what forms the basis of academic publishing (Janke 2011: 154). After copy-editing, design and marketing costs, the amount saved on physically printing the object may not be as large as imagined. Even then, as Janke (2011) explains, the money saved on paper, printing and distribution cannot translate into a direct saving for electronic publishers as print-only expenses are offset by additional digital-only costs that must be taken into consideration. These costs may range from converting the digital file from the format in which the work was created into a useable format, to securing digital rights, creating and maintaining the software on which the electronic copy is made available, and adjusting print runs to reflect the presence of an electronic copy of the same work (Janke 2011). In addition, smaller print runs usually mean a bigger cost per unit.

Libraries can therefore not expect publishers or aggregators to offer them e-books at greatly reduced rates, but the pricing models that businesses make available to libraries can be prohibitively expensive with complicated restrictions attached to them. Morris and Sibert maintain that there is currently no ideal business model as all models strive to be attractive to libraries, while generating an income for the business, and at the same time taking into consideration issues of copyright and digital rights management (Morris \& Sibert 2011: 98). Because not all publishers run their companies alike, business models are not yet standardised. However, the types of business model that publishers commonly offer are a subscription model, a purchase or perpetual access model, and rental or pay-per-view. Some models offer additional restrictions or elements such as single or multiple use specifications or patron-driven acquisition features.

There seems to be no overall preference by librarians for one particular business model. If perpetual access is preferred, as in Vasileiou, Hartley and Rowley's study (2012) of librarians at seven UK academic libraries, this may be 
because it is the closest model to traditional print purchase models. In a 2011 South African study of academic librarians' use of e-books, fourteen of the twenty-five librarians surveyed stated that their institutions liked the subscription model best, followed by the perpetual access model (Zinn \& Langdown, 2011: 112). However, Collins (2012) found that libraries no longer like the subscription model - they would prefer to purchase smaller packages - and predicts the end of the "big deal" if publishers do not come up with more creative e-book packages for libraries.

Vasileiou, Hartley and Rowley's study found that business models are considered one of the biggest challenges for librarians. Librarians are quoted as saying they find business models particularly confusing in their range of offerings and their "complexity"; they also do not feel that the offerings are particularly transparent (Vasileiou, Hartley \& Rowley 2012: 34). Being unsure of a product creates a lack of confidence when called to make a purchase decision, resulting in the wrong decision - or none at all - being made. Vasileiou, Hartley and Rowley say that ultimately it seems that librarians are still "feeling their way" around the different models, viewing and reviewing the strong and weak points of each (Vasileiou, Hartley \& Rowley 2012: 30).

Libraries should be aware of a fourth model for e-book acquisition: that of open access. The Open Access (OA) movement encourages the sharing of academic content free of charge and is growing as a distribution channel for digital materials. The Open Access model is an alternative to conventional publishing business models. A 2012 survey by Intech, an Open Access publisher, of librarians and library users in relation to Open Access, found that $64 \%$ of librarians surveyed would prefer to see a mixed business model available to them in the future - one that includes OA as well as other forms of access (Intech 2012). While offering some content free of charge would not generate any profit for publishers, doing so could be a strategic gesture of goodwill on the part of publishers.

At this stage, the optimal model has not yet been found (Wilkie 2012). Schroeder and Wright (2011) comment that publishers have not found the perfect business models because they still view print as their primary business and electronic publishing as less important (2011: 216). Carreiro (2010) agrees that e-books should be considered an integral part of publishing, instead of a subsidiary of print. Anderson feels that e-book suppliers should make all attempts to offer libraries business models that work for them, both from a pricing and a content perspective. Libraries must be willing to buy into the models on offer because the publishers' own survival may be determined by the survival of libraries (Anderson 2009: 136). Publishers should be aware that Open Access can become a realistic option for libraries on which to build their e-book collections.

Though not Open Access, patron- or demand-driven acquisition (PDA or DDA) is one way publishers have become more creative in what they offer libraries. Libraries typically add certain items to their collections in order to have them readily available, should they be requested by patrons in the future. PDA is a way of supplying items only when they are needed, thus changing the acquisitions process from one where items are bought "just in case" to one where they can be bought "just in time". PDA is not a new concept (Schroeder \& Wright 2011: 218). Libraries have been purchasing items on the request of patrons for a long time. The model for e-books, however, is a more sophisticated way of processing requests, much of it automated, with a much-reduced delivery time because of the nature of electronic products. There are different models of PDA, but often a list of titles is made available through which users may browse. Once a title has been clicked on or read a certain number of times, or more than a predefined number of pages has been downloaded, the book is purchased by the library. In this way, users are able to find and use content that the library did not previously own. PDA is, therefore, a way for libraries to allow their purchases to reflect user demands and, in addition, improve the cost per use of each item as a purchase only takes place if there is evidence of consistent use (Schroeder \& Wright 2011: 218).

Johnson (2011) points out that if a library wishes to embark on a PDA programme, there are many factors to consider and the following questions should be answered. Firstly, what is the step in the user's browsing process that activates the purchase? Are there a certain number of clicks, for example, that trigger a purchase, or a certain number of loan periods where after purchase is automatic? Secondly, how much content in an e-book collection should be made available for PDA? Would newer books be included, for example? How many users at a time will the system allow to make use of PDA? Will patron-driven acquisitions be able to be made available for loan through interlibrary arrangements?

Schroeder's study (2012) at Brigham Young University found that, even if the cost of an e-book was the same as its print equivalent, the cost-per-use of e-books purchased via PDA was significantly lower compared to books purchased in the traditional way. Although return on investment thus seems to be better on books purchased using PDA, Schroeder emphasises that libraries should not discard traditional acquisition models altogether. Collections, she says, should not only be built on what is needed at that moment (Schroeder 2012). Levine-Clark (2011) agrees with this sentiment, but not for the same reasons. He predicts that once vendors have refined the PDA process and once there are enough titles available to make it viable, patron-driven acquisition could become the only method of collection building for libraries.

For now, though, there is still much for acquisitions teams to do. Levine-Clark stresses the importance of maintaining the number and "mix" of titles available for selection so that what is offered to users is useful to them, will fit in with the overall library collection, and will fall within the library's budget (Levine-Clark 2011). Acquisitions librarians, therefore, must still play a role in the direction their collections take by customising their PDA offerings to ensure new purchases still fit into the collection development policy of the institution. It is also the job of the acquisitions or subject librarian to exercise oversight on what titles are never selected - and can thus be removed from the PDA cluster - and what new titles may be available to be added to the pool. Schroeder \& Wright add that there may be some subject areas where print books will still be preferred and, unless the library wants duplications, the PDA pool should not include titles that are already available on the shelves (Schroeder \& Wright 2011: 220). 
For Smith (2011), a big problem with PDA is that it allows only those "engaged with the technology" to have an influence on what makes up the library's collection. Those users who expect what the library stocks to be sufficient for their needs will not have their needs met. In addition, little-used but important titles, particularly classics, may never be selected, yet they are foundational texts that should be part of a collection. From a publisher's perspective, PDA will mean fewer books bought "just in case" (Seger \& Allen 2011). This could mean that publishers will become even more selective in what they choose to publish. For scholars who rely on publishing for promotion, this could be a serious drawback (Levine-Clark 2010: 205).

Anderson calls patron-driven acquisition an important "game-changer" in the current library environment - it is one of the issues that libraries must take note of and to which they must adapt their acquisitions processes, or risk becoming obsolete (Anderson 2009: 139). Levine-Clark (2011) feels that, at the very least, PDA will mean the end of interlibrary lending (ILL) as far as digital books are concerned as libraries will purchase or borrow e-books they do not already have in their collection directly from suppliers as they are needed. ILL will, however, still have a place for items that are not digitally available.

\section{Copyright, licensing and digital rights management}

Copyright law protects a work from being copied and passed off as someone else's creation. The South African Copyright Act of 1978 includes a fair dealing exemption which allows works to be copied and used by anyone "to the extent reasonably necessary" for purposes such as private use, research, or reporting, provided citations are provided for work that is not for personal use (Masango 2009: 233). Under copyright law, for example, copies may be made of a chapter of a book, those pages may be lent to a friend, and the friend may use them for scholarship. Books, both print and electronic, are protected by copyright law. Digitising a print book is equivalent to making a copy of it; doing so for commercial gain is illegal. Copyright became an issue for Google Books because it was making digital copies of books, whether or not they were still in copyright. Google Books contravened United States copyright law when it digitised books that were in copyright without first obtaining permission from the creators of the works, the rights holders (Price 2011: 58). Of particular concern was the copyright of orphan works - those still in copyright but where the author cannot be located or contacted to secure an agreement to allow digitisation. A settlement was reached in 2009 between Google and copyright holders whereby in-print copyright holders had to give permission for Google to include their books on the website, while out-of-print copyright holders' books would be included until they opted out (Grimmelmann 2011: 705). The settlements resulted in opposition from third parties on, among others, fair trade grounds; subsequently, the settlement was rejected in March 2011 (Grimmelmann 2011: 707). In November 2013, the lawsuit was dismissed. The judge stated that he believes Google shows "respectful consideration for the rights of authors ... without adversely impacting the rights of copyright holders" (Chin quoted in Shankland 2013). In his opinion, Google Books has brought great value to "all society", inclusive of, but not restricted to, students, teachers, librarians, scholars, the "print-disabled", remote populations, authors and publishers (Chin quoted in Shankland 2013).

Electronic books may be protected by copyright, but they are also subject to licensing agreements which publishers or e-book aggregators impose in order to restrict the re-use of content to authorised users only (Masango 2009: 234). Libraries are bound by licensing agreements negotiated with their e-book suppliers. Quoting Cohen writing in 1998, Masango (2009: 235) says that libraries are bound by their licensing agreements over copyright law as "contract law rather than copyright law is paramount'. Therefore, while print books are bound by copyright law only, it is the licensing agreement that determines the use of e-book content in libraries.

Digital Rights Management (DRM) concerns the restrictions that have been agreed to under licensing terms. DRM enforces these restrictions by imposing certain limits via the software on which the e-book is being accessed. DRM software can, for example, allow only authorised users access to content, or it can limit the downloading, printing or copying of the text. DRM is thus more restrictive than copyright; copyright allows information to be used to a certain extent by anyone.

A CILIP Policy Department paper on the problems associated with adding e-books to library collections identifies licensing agreements as a key issue faced by librarians, both public and academic. While libraries acquire print books according to the "first-sale doctrine" (once sold, publishers no longer have control over what is done with the book), ebooks are not physically distributed, and how libraries make e-books available to the public is dependent on the licensing agreement it has with the publisher or aggregator (CILIP Policy Department, 2012). Accordingly, licensing agreements have implications for ILL, and any allowances have to be written into the agreement. According to focus groups held with librarians at nine UK universities as part of the JISC Observatory project, librarians feel that licensing agreements are too complex, being hard to understand and sometimes difficult with which to comply (Armstrong \& Lonsdale 2009: v). While DRM software can force complicity, it can, in many cases, be removed (Blankfield 2012: 88), making the library once again liable for unauthorised use.

In a landmark case in which it was argued that the U.S. state of Kansas owned the e-content for which it had paid its vendor, the state librarian was able to negotiate the transfer of the state's e-book collection from one vendor (OverDrive) to another (3M), without having to pay additional licensing fees (Kelly \& Lee, 2011: 12), thus giving librarians hope that it is possible for licensing agreements to be overturned to a certain extent. Vasileiou, Rowley and Hartley (2012) found that licensing negotiations - identified as one of the biggest challenges (alongside business models) of the management of ebooks in academic libraries - can be better handled through a consortium, where a team effort can make negotiations on the part of libraries more effective (Vasileiou, Rowley \& Hartley 2012: 286). 


\section{Format}

Format is an expensive consideration when it comes to purchasing e-books for libraries. Some e-book formats require specialised software or hardware to display. PDF (portable document format) has been found to be the preferred format for librarians because of its ease of use, search capabilities and text linking (Vasileiou, Hartley \& Rowley 2012: 29). It could be argued that the familiarity of the format adds to its appeal. Still, there are as yet no format standards for e-books, creating an uncertainty within e-book collection development of what format to purchase for the future (Coulson quoted in Wilkie 2012). The e-PUB (electronic publication) format is as close to a global standard as can be at the moment because it can be read on almost any device. It is, however, the format that has the most DRM limitations attached to it (Delquie \& Polanka 2011: 137).

A blog post by Pooley (2013) argues that publishers should consider producing formats that are the most practical for researchers to use - those without any restrictions and which allow for annotation and sharing in particular. He argues that some academics would rather not read a book than struggle with its format, which is often device-specific, its DRM restrictions and what are, according to him, complicated features. Format is also linked to the preservation of e-books. A change in format in the future might impact on access to the archives (Crosetto 2011: 126).

\section{Hardware and software}

Whichever format libraries choose for their e-books, they must provide the relevant hardware and software so that patrons can make use of the collection. For example, a library should provide enough work-stations, with sufficient memory capabilities on which users can access e-books. Work-station operating systems should be compatible with library-supplied e-book requirements and the correct version of reading software must be available on the system. A stable power supply and adequate bandwidth is necessary for downloads and on-screen reading. Devices should be available for loan if the library has purchased a large number of e-books in the proprietary software of an e-reader supplier.

The growth of e-reference material and e-journals has already meant that libraries have converted much of their space into accommodation for work-stations. Bennett (2009) writes about three paradigms that have driven the design of library spaces over time: one, the reader-centred approach, where readers were the focus; the second, the book-centred approach, where the physical collection was the focus; and the third and latest, the learning-centred approach, where work space with access to the library's virtual collection is provided. If the introduction of e-books means fewer print books, libraries can afford to convert former shelf space into accommodation for more work-stations. An increase in workstations would be needed, not only because of more library resources being offered electronically, but also because, unlike e-journal articles which can often be read relatively quickly or downloaded and read elsewhere at another time, ebooks, often not downloadable in their entirety, need to be used for a longer length of time at the point of access. E-book aggregators and vendors usually provide their own platform from which to access their material. So, for access to their ebooks, the library would more often than not need to ensure internet browsers are installed on each computer in the library. If e-books are not read via a browser, programs compatible with the format of the e-books are required. Because there is no current standard for e-book format, this could mean users might find it difficult to access e-books from outside the library. The library could ensure that it, at least, offers complete access to its e-book collection on site, no matter what the format is.

With the growth in popularity of e-reading devices such as tablets and dedicated e-readers over the past few years, this area of technology is a concern for libraries. One of the reasons e-readers have not been introduced to academic libraries in the past is the concern about format (Wexelbaum \& Miltenoff 2012: 279). This concern translates to a hesitancy to commit to one make of e-reader. Buying an e-reader that is only compatible with, for example, e-books in the e-PUB format is not an effective use of library resources, especially if e-PUB e-books do not make up a vast percentage of the collection. Ultimately, what is needed is an e-reader that has the ability to read a variety of formats (Wexelbaum \& Miltenoff 2012: 279). A lending programme run at Texas A\&M University proved to be extremely popular - so much so, that the lending period had to be changed from two weeks to one - and seemed to indicate that lending e-readers, Kindles in this case, could be something for libraries to explore for leisure reading titles (Clark 2009). While the display on e-readers such as Amazon's Kindle may be easy to read because of the lack of backlighting and the use of e-ink, ereaders are notoriously bad at displaying anything other than text, which is why they are most popular for leisure reading. Graphs and tables found in articles and textbooks would, for example, not always render correctly on an e-reader. It is for this reason that Tees suggests that universities should not yet introduce e-readers on a large scale (2010: 184). Clark's report predicts that the future of the Kindle (and e-readers in general) for academic use will rely on hardware that allows for academic publications, inclusive of graphs, to be viewed correctly (Clark 2009: 149). With the ever-growing popularity of tablet devices, such as Apple's iPad, with their colour screens and Kindle applications, the library may have found its solution.

The 2012 Educause Center for Applied Research (ECAR) study of undergraduate students and information technology examined, among other things, the technologies that undergraduate students prefer to use. The report found that, while undergraduate students may be familiar and comfortable with a wide range of technological devices, they do not want to make use of every technology for their studies (Dahlstrom 2012: 10). Zimerman (2011: 97) and Janke (2011: 161) both suggest exploring student interest in using their cell phones as e-readers. The 2011 South African census found that mobile telephones proliferate in the country: $88.9 \%$ of households own a cell phone (Statistics South Africa, 2012) and Vosloo (quoted in Zell, 2013: 3) considers them a very real and powerful tool to be used alongside print for educational purposes. 
From the perspective of publishers, there is an uncertainty about committing to publishing their content to be read on e-readers as they are unsure how many of their potential readers or libraries own e-readers, and, if they do own them, what type they are (Janke 2011: 161). Publishers need to make a strategic decision on whether to limit their output to one format technology or expand to include a number of them, all of which carry a cost.

\section{Conclusion}

Libraries were some of the earliest advocates of e-books, digitising their collections for the sake of preservation and sharing. Their desire to provide content for their users is being tested by the challenges of growing e-book collections. Some of these challenges are dealt with in much of the literature on e-books and have been discussed in this paper. While growing e-book collections is being challenged by libraries and librarians holding onto their traditional ways of doing business, collection growth can be encouraged through library policies directed at e-books and the procurement and installation of the necessary hardware and software. Understanding business models and purchasing the best one is most crucial to the growth of the e-book collection in a library.

\section{References}

Abdullah, N. \& Gibb, F. 2008. Students' attitudes towards e-books in a Scottish higher education institute: part one. Library review, 57(8): 593-605.

Anderson, R. 2008. Future-proofing the library: strategies for acquisitions, cataloging, and collection development. The serials librarian, 55(4): 560-567.

Anderson, R. 2009. Librarians and publishers in the eye of the format-migration storm. Information services and use, 29(4): 133-141.

Armstrong, C. \& Lonsdale, R. 2009. E-book collection management in UK university libraries: focus groups report. London: JISC collections. Available: http://observatory.jiscebooks.org/reports/e-book-collection-management-in-ukuniversity-libraries-focus-groups-report/ [2012, August 1].

Bennett, S. 2009. Libraries and learning: a history of paradigm change. portal: libraries and the academy, 9(2): 181-197.

Blankfield, S. 2012. Towards a digital spine. Publishing research quarterly, 28: 79-92.

Breeding, M. 2012. The systems librarian: coping with complex collections - managing print and digital. Computers in libraries, 32(7): 23-26.

Carreiro, E. 2010. Electronic books: how digital devices and supplementary new technologies are changing the face of the publishing industry. Publishing research quarterly, 26: 219-235.

CILIP. Policy Department. 2012. Ebook acquisition and lending briefing: public, academic and research libraries. London: CILIP. Available: http://www.cilip.org.uk/get-involved/policy/statements and briefings/Documents/E-book acquisition and lending by libraries - longer briefingv2.pdf [2012, September 19].

Clark, D.T. 2009. Lending Kindle e-book readers: first results from the Texas A\&M University project. Collection building, 28(4): 146-149.

Collins, T. 2012. The current budget environment and its impact on libraries, publishers and vendors. Journal of library administration, 52(1): 18-35.

Crosetto, A. 2011. The use and preservation of e-books. In No shelf required: e-books in libraries. S. Polanka, Ed. Chicago: ALA. 125-134.

Dahlstrom, E. 2012. ECAR study of undergraduate students and information technology. Louisville, Co.: EDUCAUSE Center for applied research. Available: http://net.educause.edu/ir/library/pdf/ERS1208/ERS1208.pdf [2012, September 20].

Delquie, E. \& Polanka, S. 2011. E-book standards. In No shelf required: e-books in libraries. S. Polanka, Ed. Chicago: ALA. 135-151.

Dewan, P. 2012. Are books becoming extinct in academic libraries? New library world, 113(1): 27-37.

Galbraith, J. 2011. E-books on the internet. In No shelf required: e-books in libraries. S. Polanka, Ed. Chicago: ALA. 1-18.

Gardiner, E. \& Musto, R.G. 2010. The electronic book. In The Oxford companion to the book. M.F. Suarez, S.J. Woudhuysen \& H.R. Woudhuysen, Eds. Oxford: Oxford University Press. 164-171.

Gomez, J. 2008. Print is dead: books in our digital age. New York: Macmillan.

Grimmelmann, J. 2011. The elephantine Google Books settlement. Journal of the Copyright Society of the U.S.A. 58(3): 701-724. Available: http://works.bepress.com/cgi/viewcontent.cgi?article=1031\&context=james_grimmelmann [2013, February 13].

Intech. 2012. Assessing the role of librarians in an open access world. Rijeka, Croatia: Intech.

Janke, R. 2011. The future of academic book publishing: e-books and beyond. In No shelf required: e-books in libraries. S. Polanka, Ed. Chicago: ALA. 153-163.

Johnson, R. 2011. Purchasing options in patron-driven acquisitions. Against the grain. 23(3). Available: http://www.against-the-grain.com/2011/07/v23-3-purchasing-options-in-patron-driven-acquisitions [2012, August 14].

Johnson, S., Evensen, O.G., Gelfand, J., Lammers, G., Sipe, L. \& Zilper, N. 2012. Key issues for e-resource collection development: a guide for libraries; draft. The Hague: International Federation of Library Associations and Institutions.

Joint, N. 2010. The electronic book: a transformational library technology? Library review, 59(2): 83-91.

Kelley, M. \& Lee, M. 2011. Kansas state librarian to transfer e-content for free. Library journal, 18: 12. 
Levine-Clark, M. 2011. Developing a model for long-term management of demand-driven acquisitions. Against the grain. 23(3). Available: http://www.against-the-grain.com/2011/07/v23-3-developing-a-model-for-long-term-management-ofdemand-driven-acquisitions [2012, August 14].

Link, F.E. 2012. Are we there yet? An analysis of e-book equivalent coverage in highly-circulated titles at the College of New Jersey Library. Collection building, 31(4): 132-135.

Littman, J. \& Connaway, L.S. 2004. A circulation analysis of print books and e-books in an academic research library. Library resources and technical services, 48(4): 256-262.

Masango, C.A. 2009. Understanding copyright in support of scholarship: some possible challenges to scholars and academic librarians in the digital environment? International journal of information management, 29(3): 232-236.

Medeiros, N. 2011. Cry not for books. OCLC systems \& services, 27(2): 84-86.

Medeiros, N. 2012. King of the hill. OCLC systems \& services, 28(2): 64-66.

Morris, S. \& Sibert, L. 2011. Acquiring e-books. In No shelf required: e-books in libraries. S. Polanka, Ed. Chicago: ALA. 95-124.

Pooley, J. 2013. Digital rights management: downloads, downers and a call for PDF publishing. The guardian. 26 February. Available: http://www.guardian.co.uk/higher-education-network/blog/2013/feb/26/digital-rights-managmentpdf-books [2013, March 4].

Price, A.C. 2009. How to make a dollar out of fifteen cents: tips for electronic collection development. Collection building, 28(1): 31-34.

Price, K. 2011. E-books for free: finding, creating and managing freely available texts. In E-books in libraries: a practical guide. K. Price \& V. Havergal, Eds. London: Facet. 53-67.

Rowlands, I., Nicholas, D., Huntington, P., Clark, D., Jamali, H. \& Nicholas, T. 2009. JISC national e-books observatory project: key findings and recommendations - final report, November 2009. London: JISC collections.

Rowlands, I., Nicholas, D., Jamali, H.R. \& Huntington, P. 2007. What do faculty and students really think about e-books? Aslib proceedings, 59(6): 489-511.

Schell, L. 2011. The academic library e-book. In No shelf required: e-books in libraries. S. Polanka, Ed. Chicago: ALA. 75-93.

Schroeder, R. 2012. When patrons call the shots: patron-driven acquisition at Brigham Young University. Collection building, 31(1): 11-14.

Schroeder, R. \& Wright, T. 2011. Electronic books: a call for effective business models. New library world, 112(5): 215221

Seger, R. \& Allen, L. 2011. A publisher's perspective on PDA. Against the grain. 23(3). Available: http://www.against-thegrain.com/2011/07/v23-3-a-publishers-perspective-on-pda [2012, August 14].

Shankland, S. 2013. Judge dismisses authors' case against Google Books. CNET. 14 November. Available: http://news.cnet.com/8301-1023_3-57612336-93/judge-dismisses-authors-case-against-google-books/ [2013, December 10].

Smith, S.A. 2011. PDA: Driving off the cliff or, new wine in old bottles. Against the grain. 23(3). Available: http://www.against-the-grain.com/2011/07/v23-3-op-ed-notes-from-mosier [2012, August 15].

Statistics South Africa. 2012. Census 2011: statistical release - P0301.4. Pretoria: Statistics South Africa.

Tees, T. 2010. Ereaders in academic libraries: a literature review. The Australian library journal: journal of the Australian Library and Information Association, 59(4): 180-186.

Thompson, J.B. 2005. Books in the digital age: the transformation of academic and higher education publishing in Britain and the United States. Cambridge: Polity.

Treptow, R. \& James, M. 2011. Use of online knowledge resources by prominent South African researchers. South African journal of libraries and information science, 77(1): 64-74.

Tucker, J.C. 2012. Ebook collection analysis: subject and publisher trends. Collection building, 31(2): 40-47.

Vasileiou, M., Hartley, R. \& Rowley, J. 2012. Choosing e-books: a perspective from academic libraries. Online information review, 36(1): 21-39.

Vasileiou, M., Rowley, J. \& Hartley, R. 2012. The e-book management framework: the management of e-books in academic libraries and its challenges. Library \& information science research, 34: 282-291.

Wexelbaum, R. \& Miltenoff, P. 2012. Challenges to e-reader adoption in academic libraries. The reference librarian, 53(3):270-283.

Wilkie, T. 2012. Librarians and publishers still have problems with e-books. Research information. 20 August. Available: http://www.researchinformation.info/news/news_story.php?news_id=992 [2012, November 29].

Zhao, S. \& Zhao, W. 2010. Addressing the challenge: cataloguing electronic books in academic libraries. Evidence based library \& information practice, 5(1): 93-103.

Zimerman, M. 2011. E-readers in an academic library setting. Library hi tech, 29(1): 91-108.

Zinn, S. \& Langdown, N. 2011. E-book usage amongst academic librarians in South Africa. South African journal of libraries and information science, 77(1): 104-115.

Zell, H. M. 2013. Print vs. electronic, and the "digital revolution" in Africa. African book publishing record, 39(1): 1-19. 